\title{
Capacity Building: Continuity and Change
}

\author{
Calvin W. L. Ho ${ }^{1}$
}

Published online: 12 December 2019

(C) National University of Singapore and Springer Nature Singapore Pte Ltd. 2019

As the year draws rapidly to a close, I am pleased to present the final instalment of this year's journal volume. The building of (primarily scholastic) capacity to address bioethical issues and to advance bioethical goals, particularly where the Asian and Pacific regions are concerned, continues to be prominent in the published papers and activities of the journal.

We welcomed the new year with an international research seminar that sought to consider the ethical implications of the Astana Declaration on endeavours directed at Universal Health Coverage (UHC) in a number of Asia-Pacific countries. Some of the works presented in this seminar have been published in the March instalment of the journal, which had people-centeredness in UHC as its central theme (Ho and Caals 2019). In the second instalment of the journal for the year, we published papers that not only reached back to earlier discussions on ethical deliberations around biodiversity (Lajaunie and Morand 2018) but also forward to ethical approaches in the evaluation of the Big Data phenomena in health research. As is now clear, the special section (Schaefer 2019) on Big Data in this journal issue served as a forerunner to our third instalment of the journal, comprising papers that are dedicated to that topic as a special theme (Laurie and Tai 2019). I am also pleased to note that the Global Forum on Bioethics in Research (GFBR) meeting was successfully held in Singapore on 12 and 13 November this year, as announced in an earlier editorial (Ho and Hunt 2019). Both GFBR and this journal share the goal of strengthening the capacity of scholars to recognise, consider and respond to current and anticipated bioethical challenges. It is hence a befitting end to the year for me to present the two prize winning essays (first prize: Subramani 2019; second prize: Sasi 2019) and an essay that earned honorary mention (Chua 2019) in our annual ABR Young Scholar Award. I take this opportunity to congratulate the winners, and to thank all competition participants, as well as our panel of judges: Professor Ruth Macklin, Professor Vikki A. Entwistle and Professor Alastair V. Campbell. Additionally, I am delighted to present in this journal issue an update from our colleagues in Japan on withdrawal of treatment (Nakazawa et al.

Calvin W. L. Ho

cwlho@hku.hk

1 Centre for Biomedical Ethics (CBmE), Yong Loo Lin School of Medicine, National University of Singapore, Singapore 
2019), two papers on the ethics of human stem cell research from our colleagues in Malaysia (Sivaraman 2019; Gopalan 2019) and a comparative study on medical ethics education by our colleagues in Indonesia and the Netherlands (Muhaimin et al. 2019).

This journal issue draws my tenure as Editor-in-Chief to a close. I cannot adequately articulate how humbled I am in being given the privilege to serve in this role, and I thank the Yong Loo Lin School of Medicine of the National University of Singapore and Springer Nature for this invaluable opportunity. I am also grateful to the members of the Editorial Board, as well as the journal's Editorial Team and reviewers, for their steadfast support and generous contributions. Finally, I wish all readers happy holidays and a successful new year ahead.

\section{References}

Chua, Hillary. 2019. Healthcare access for the deaf in Singapore: overcoming communication barriers. Asian Bioethics Review 11 (4). https://doi.org/10.1007/s41649-019-00104-3.

Gopalan, Nishakanthi. 2019. The shortage of Malaysian stem cell ethics in mainstream database: a preliminary study. Asian Bioethics Review 11 (4). https://doi.org/10.1007/s41649-019-00102-5.

Ho, Calvin W.L., and Karel Caals. 2019. People-centred universal health coverage in the Asia-Pacific. Asian Bioethics Review 11 (1): 1-3. https://doi.org/10.1007/s41649-019-00084-4.

Ho, Calvin W.L., and Adrienne Hunt. 2019. Biodiversity, Big Data and genome editing. Asian Bioethics Review 11 (2): 129-132. https://doi.org/10.1007/s41649-019-00091-5.

Lajaunie, Claire, and Serge Morand. 2018. Guest editorial: a pragmatic approach of ethics in interdisciplinary research on biodiversity conservation. Asian Bioethics Review 10 (4): 241-243. https://doi.org/10.1007 /s41649-018-0073-9.

Laurie, Graeme T., and Shyong Tai E. 2019. Delivering a practical framework for ethical decision-making involving big data in health and research. Asian Bioethics Review 11 (3): 223-225. https://doi.org/10.1007 /s41649-019-00098-y.

Muhaimin, Amalia, Derk Ludolf Willems, Adi Utarini, and Maartje Hoogsteyns. 2019. What do students perceive as ethical problems? A comparative study of Dutch and Indonesian medical students in clinical training. Asian Bioethics Review 11 (4). https://doi.org/10.1007/s41649-019-00101-6.

Nakazawa, Eisuke, Keiichiro Yamamoto, Reina Ozeki-Hayashi, and Akira Akabayashi. 2019. Why can’t Japanese people decide? - $\mathrm{w}$ ithdrawal of ventilatory support in end-of-life scenarios and their indecisiveness. Asian Bioethics Review 11 (4). https://doi.org/10.1007/s41649-019-00107-0.

Sasi, Aiswarya. 2019. Ethical issues concerning legislation in late-term abortions in India. Asian Bioethics Review 11 (4). https://doi.org/10.1007/s41649-019-00105-2.

Schaefer, G. Owen. 2019. Ethics in the era of Big Data. Asian Bioethics Review 11 (2): 169-171. https://doi. org/10.1007/s41649-019-00092-4.

Sivaraman, Mathana Amaris Fiona. 2019. Ethical guiding principles of "do no harm" and the "intention to save lives" in relation to human embryonic stem cell research: finding common ground between religious views and principles of medical ethics. Asian Bioethics Review 11 (4). https://doi.org/10.1007/s41649019-00103-4.

Subramani, Supriya. 2019. The rhetoric of the 'passive patient' in Indian medical negligence cases. Asian Bioethics Review 11 (4). https://doi.org/10.1007/s41649-019-00106-1.

Publisher's Note Springer Nature remains neutral with regard to jurisdictional claims in published maps and institutional affiliations. 